\title{
The Relationship Between Guests' Knowledge Awareness and Their Behaviors in Submitting Complaints (Applied on a Sample of Five Star Hotels in Sharm El-Sheikh)
}

\author{
Ahmed Anwar Elsaed \\ Omnia Mohammed Hassan
}

Faculty of Tourism and Hotels, Mansoura University

\begin{abstract}
There are many factors that affect guests' complaining behaviors as follows: guests' lack of knowledge about the accessibility of making complaints, perceived justice, and expected costs and efforts of complaining. This study aims to determine the effect of guests' awareness towards these factors on their complaint's behaviors. The study also aims to determine if there is a difference in guests' awareness towards the research variables backs to their demographic characteristics. In order to achieve these objectives, a questionnaire form was developed and directed to a random sample of guests in a five star hotels in Sharm El-Sheikh. A total of 400 questionnaires were distributed among them; only 377 forms $(94.25 \%)$ were valid. The results indicated that guests have not knowledge enough about the entity they should go when they face a problem or bad service, and they didn't realize that there is justice in hotels towards complaints handling. The respondents usually take a great negative action through speaking to friends and relatives about their bad experience Based upon the findings, some recommendations were suggested and directed to hotel managements. One of the main recommendations was putting guidelines and instructions in clear places inside the hotel which direct guests to how delivering their complaints.
\end{abstract}

Keywords: Guests' Awareness, Guests' Behaviors, Complaints, Sharm El-Sheikh Hotels.

\section{Introduction}

Emir (2011) found that complaints arise when the hotel does not interest in guests' problems. From a guests' perspective, complaining to the hotel is a negative action. Thus, it is important to solve any problem derived from guest complaints. Hotels face a problem of guests' tendency to boycott its service without providing any reason or complaint. Guests choose not to complain because (1) lack of competency and time to complain, (2) lack of knowledge about the accessibility of making complaints and (3) belief that there is no justice with complaint handling. (Badghish et al., 2015; Chan et al., 2017).

The study's core problem lies in that most studies concerning consumer complaint behavior only focus on complaint intention or complaint action (Zheng et al., 2009; Namkung et al., 2011; Salim et al., 2017). Meanwhile, little studies have investigated in the effect of knowledge awareness on complaint behaviors especially in hotel sector. The importance of study focuses on guests' lack of information about complaints delivering accessibility, perceived justice, and expected costs and value of complaining and its relationship with guests' intention to complaint. Hence, the study aims to identify the relationship between guests' knowledge awareness and their behaviors in submitting complaints and determining if there is a difference in guests' awareness towards the research variables backs to their demographic characteristics. Limitations of the study are divided into two limitations. Human limitations represented in guests of Five Star Hotels in Sharm El-Sheikh. Time limitations represented in addressing questionnaire forms to the investigated guests in the period from $15^{\text {th }}$ of July 2019 to $18^{\text {th }}$ of December 2019.

\section{Research Hypotheses}

The research hypotheses could be suggested as follows:

H1: There are significant differences between the guests in their knowledge awareness returns to demographical data ("H 1.1" gender, "H 1.2" educational level, and "H 1.3" nationality). 
H2: There is a significant effect of guests' knowledge awareness (about "H. 2.1" complaints delivering accessibility, "H. 2.2" perceived justice, and "H. 2.3" expected costs and efforts of complaining) on guests' complaint behavior.

Figure 1: The Proposed Research Framework and Hypotheses



\section{Literature review}

\section{The Background of Complaint Behavior}

Buttle (2004) argued that complaints consider as a behavioral expression of an unfavorable situation towards an object, person, or attitude. Most literature discusses complaining as a behavioral result of a perceived gap between customers' expectations and the real performance of the product or service (Filip., 2013). Zheng et al., (2009) believed that complaining is one way to relieve customers' feeling when they receive unfair sales practices that make them disappointed with poor product or service standard comparing to its price. In addition, Chelminski, and Robin (2011) defined customer complaint behavior as customers' responses "triggered by perceived dissatisfaction which is neither psychologically accepted nor quickly forgotten with consumption of a product or service" (p. 368).

Many studies handled customer complaints from different perspectives. Aljasser and Sasidhar (2013) investigated the influence of gender, age, social status, and educational level on seven general customer complaint factors (lack of product knowledge, bad service, uncleanliness, employees' rudeness, incorrect billing, inattention, and unwillingness to correct problems), they found out that specific customers have special demands backs to their demographic data. For instance, Salleha et al. (2015) noted that older customers tend to take complaint actions more than younger consumers. They also found that customers with higher education tend to avoid complaint behavior.

There are many factors that increase the tendency to making a complain include (Kim et al., 2010: Erdogan and Norman, 2011):

- Obtaining satisfactory results after complaining.

- Thought that the organization interests in handling the problem.

- Importance of the product/service to the customer.

- Complaining is not costed.

- Positive perception toward complaining attitude. 
- Realizing that if the customer does not complain, others will be harmed.

- Thought that the problem will be controlled.

Nikbin et al. (2012) suggested that customers' intention to complain is relevant to their evaluation of the value of complaining and probable consequences from making a complaint. Salim et al., (2018) set four main purposes of complaining:

- obtaining compensation: customers complain to recover their economic loss by asking a refund, compensation, or by getting the service again.

- Expressing anger: complaining may help customers to vent their anger and make them quieter.

- Improving the service: customers usually provide feedback to achieve service improvement, when they are highly needed to it.

- For altruistic reasons, some customers realize that if they do not complain, it will cause difficulties to others.

\section{Classifications of Complaint Behaviors}

Dahl and Peltier (2015) distinguished between behavioral and non-behavioral actions at the first level and between public (e.g., complain to a responsible entity, take legal actions) and private (e.g., boycott the brand, negative word of mouth) actions at the second.

Istanbulluoglu (2017) classified dissatisfaction responses to exit (stopping of treatment), voice (transferring the bad experience to service providers, friends, social media) or loyalty (do nothing). Ramphal, (2016) have described complaining behavior with such terms as "nonaction", "private action", and "public action". (p.12). Simon et al., (2015) claimed that only 1 out of 20 customers tend to complain. Most customers do not take an action because they believe that complaining is useless, or they do not have the time or the effort to complain. Meanwhile, TagEldeen (2018) interpreted that some people do not complain because the lack of knowledge about the accessibility of making complaints. Buttle (2004) (as cited from Kim et al., 2010) recommended, three categories included voice responses (no action or taking action such as voice to service provider), private responses (such as warning friends and boycott the product) and third-party responses (such as take legal actions, and action by social media). These attempts to classify customer complaint behaviors can be summarized in Figure 2.

Figure 2: Classification of customer Complaint Behaviors

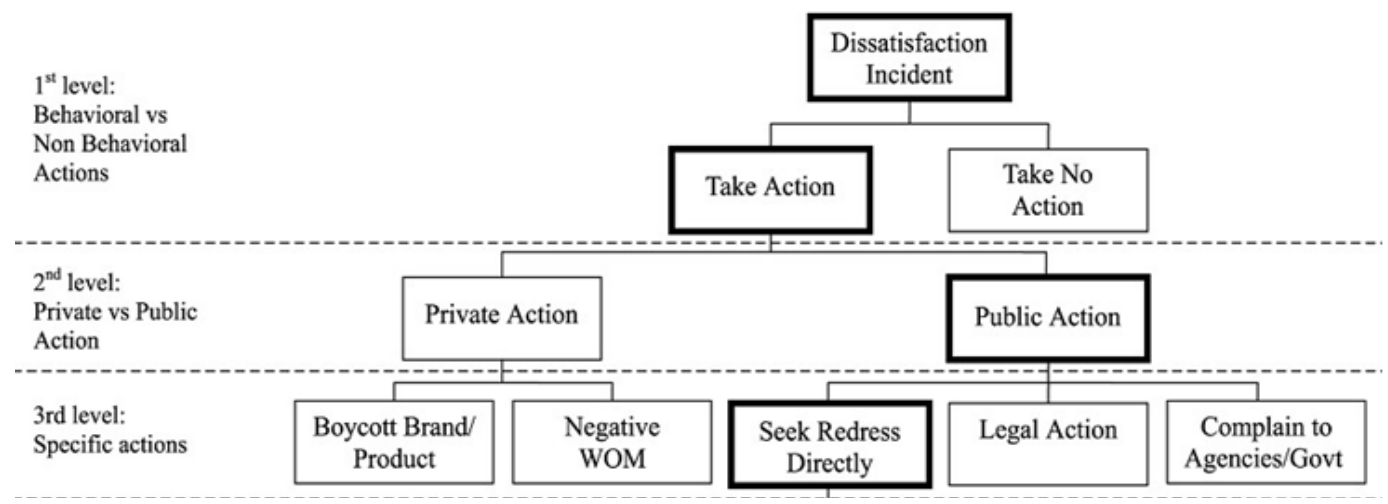

Source: Buttle (2004) (as cited from Kim et al., 2010) 


\section{Determinants of Complaint Behaviors}

According to Chan et al., (2017), guests' lack of information about the accessibility of making complaints, perceived justice, and expected costs and value of complaining influence guests' intention to complaint.

\section{Costs and value of complaining}

Ro and Wong (2012) mentioned that customers usually make a benefit \& cost analysis to take an action about complaining or not. In this sense, if the complaint's cost and the time spent for complainig provides additional benefit for the customer, it would encourage them to complain, but if the complaining cost is more than the benefit, it would make them keep silent without making any complaint (Badghish et al., 2015).

According to Mousavi and Esfidani (2013), perceived value of individuals' complaint is associated with the tendency to complain, and the tendency to complain is related with complaint behavior, that indicates that perceived value of complaint indirectly impacts on complaint behavior through the intention of complain. To prove the tendency to complain by demonstrating the mediation relationship between the decision of complaining and the perceived value of complaint. The same researchers found that many customers consider that making a complaint is very difficult and needs additional time and financial costs.

Many customers consider that making a complaint include many troubles, time waste, and financial costs. Meanwhile, some customers think that making a complaint is quite easy. (Cambra-Fierro et al., 2015). If guests believe that making a complaint to the hotel is an implemental procedure to achieve desired results and that these results provide a desirable value, this consistency may motivate the guest to be have more complaint intention. (Kim et al., 2010; Badghish et al., 2015). Chan et al., (2017) argued that costs (either moral or monetary) involved in complaining may affect guest's complaint behavior.

\section{Complaining Accessibility}

Complaint accessibility describes the simplity with which complaints procedure can be always accessed by all guests. Generally, accessible complaint procedures are not available only when guests want to complain; it should be always accessible to all guests. It is very important that hotels set the most effective method to ensure maximum accessibility when any guest need to complain. For example, placing information about complaint entities in waiting areas where be obvious to all guests. Complaints brochures may also be helpful and hotels may think of the best places which make it most effectively displayed (Einwiller and Steilen, 2015; Ramphal, 2016) . Complaining accessibility achieves when that guests will not spend money to provide a complaint; and that the procedure of complaining will not take additional time. It supposes that the ways that hotels take to handle problems arising from service failure should be obvious to customers and are adaptable to customers' needs (Nikbin et al, 2012; Demirci et al, 2015). Complaining accessibility also includes policies, procedures, and methods that hotels use to increase the communication with guests in general and specifically, their problems when they want to make a complaint (Chan et al., 2017).

\section{Perceived justice}

Sparks and McColl-Kennedy (2001) delineated that customers' perceptions about the organization willingness to provide compensation has a significant correlation with their complaint behavior and the intention to complain. Nikbin et al, (2012) found that a hotel's reputation about responsiveness to take an action about a complaint directly affects consumer complaint behavior. 
Vincent and Lam (2003) pointed out that the relation between complaining intention and the hotels willingness to solve problems as a major factor in guest complaint behavior. Guests are more likely to tell others about their unhappiness when guests found unresponsiveness about their complaints that causes guests dissatisfaction since they perceive the hotel to be at fault $(\mathrm{Li}$, 2010). Chan et al., (2017) claimed that the guest's choice of complaint response type depends on the willingness to handle guests' complaints by the hotel.

On other hand, Verhagen et al., (2013) found that organization practices and responsiveness to handle customer complaints have no significant relationship with complaint intention. However, Einwiller and Steilen (2015) mentioned that "if a firm has a strong image for quality and a wellknown reputation for making adjustments, consumers are more likely to complain when they are dissatisfied" (p. 201).

Ramphal (2016) suggested that if guests believe that their complaints will be solved by the hotel, they are more likely to complain to the hotel. Meanwhile, if they think that the hotel does not interest their complaint, they may believe the complaints will be useless and prefer to remain silent and boycott the hotel. The same researcher found that higher guest's perception on the possibility of the successful complaint can support of complaint intention.

\section{Research methodology}

In order to achieve the research aim, guests in five star Sharm El-Sheikh hotels were surveyed. Sharm El-Shiekh has been chosen as a representative sample of the Egyptian hotel society because of its popularity and it have the largest number of hotels compared with other cities which have resorts in Egypt (e.g., Taba, Dahab, Hurghada, Gouna, Safaga, Marsa Alam, Ain Sokhna) (Egyptian Hotel Association "EHA", 2016). The sample equation was applied to unlimited society (Thompson, 2012) as follows:

$$
n=\frac{N \times p(1-p)}{\left.\left[N-1 \times\left(d^{2} \div z^{2}\right)\right]+p(1-p)\right]}
$$

$\mathrm{N}$ : sample size, P: percentage of the purpose of this study 0.50 , d: percentage of the error limit allowed $0.05, \mathrm{Z}$ : the standard degree used for giving general results is $95 \%$. Thus, the standard degree $=1.96$

$$
\mathrm{N}: \frac{20000 \times 0.50(1-0.50)}{\left[\left(2 r 0000-1 \times\left(0.05^{2} \div 1.96^{2}\right)+0.50(1-0.50)\right]\right.}=376.93 \simeq \mathbf{3 7 7}
$$

A total of 400 questionnaires were distributed randomly in the 20 hotels which represent $46.5 \%$ of five star Sharm El-Sheikh hotels from $15^{\text {th }}$ of July, 2019 to $18^{\text {th }}$ of December 2019, only 377 forms $(94.25 \%)$ were valid to analyze. The questionnaires were returned, and the results then analyzed. The questionnaire consisted of three sections. The first section intended to reveal the guests' demographic data. The second section intended to determine the guests' knowledge awareness about complaints delivering accessibility, perceived justice, and expected costs and value of complaining (16 attributes). The third section included 7 attributes covering guest complaint behavior. The respondents were asked to answer these statements by using a five-point Likert-type scale (Strongly agree $=5$, agree $=4$, do not know $=3$, disagree $=2$ and strongly disagree $=1)$ to determine the levels of agreement with the statements investigated. The Statistical Package for the Social Sciences (SPSS) version 25.0 was used to analyze and compute the collected data. 
The range of each level of agreement was calculated as follow:

Table 1: Questions Answered Scale

\begin{tabular}{|c|c|c|c|c|c|}
\hline Category & Strongly disagree & Disagree & Neutral & Agree & Strongly agree \\
\hline Code & 1 & 2 & 3 & 4 & 5 \\
\hline Range & $1-1.80$ & $1.81-2.60$ & $2.61-3.40$ & $3.41-4.20$ & $4.21-5$ \\
\hline
\end{tabular}

\section{Reliability Analysis}

Table 2: Reliability Analysis

\begin{tabular}{|c|c|}
\hline Number of Statements & Alpha \\
\hline 23 & 0.79 \\
\hline
\end{tabular}

Table 2 indicated that alpha coefficient of the questionnaires dimensions was 0.79 (higher than 0.70) (Pallant, 2016). This result indicated to the reliability and validity of the questionnaires for using in the study.

\section{Results and Discussion}

The results involved three main stages. Descriptive analysis was used to discover participants' responses, variance analysis for respondents' answers and regression analysis were conducted to examine the relationship between independent variables and dependent variable. The results obtained were computed and analyzed in the following tables.

Table 3: Demographic Data of Guests.

\begin{tabular}{|c|c|c|c|c|c|c|c|}
\hline \multirow{2}{*}{$\begin{array}{c}\text { Demographic } \\
\text { Data }\end{array}$} & \multirow[t]{2}{*}{ Attribute } & \multicolumn{2}{|c|}{ Statistics } & \multirow{2}{*}{$\begin{array}{c}\text { Demographic } \\
\text { Data }\end{array}$} & \multirow[t]{2}{*}{ Attribute } & \multicolumn{2}{|c|}{ Statistics } \\
\hline & & Freq. & $\%$ & & & Frea. & $\%$ \\
\hline \multirow{5}{*}{$\begin{array}{c}\text { Educational } \\
\text { level }\end{array}$} & Primary education & 0 & 0 & \multirow[b]{2}{*}{ Gender } & Male & 208 & 55.2 \\
\hline & $\begin{array}{l}\text { Average education } \\
\text { (Vocational/Secondary } \\
\text { School) }\end{array}$ & 96 & 25.4 & & Female & 169 & 44.8 \\
\hline & Institutional education & 67 & 17.8 & \multirow{3}{*}{ Nationality } & Egyptian & 131 & 34.7 \\
\hline & University education & 193 & 51.2 & & & & \\
\hline & $\begin{array}{l}\text { Postgraduate (Diploma- } \\
\text { Master-PhD) }\end{array}$ & 21 & 5.6 & & Foreign & 246 & 65.3 \\
\hline
\end{tabular}

As it can be observed from Table 3 that, among the 377 respondents, a high proportion of the tested sample $(55.2 \%)$ were male and 44.8 of guests were female. Regarding nationality, a high proportion of the tested sample $(65.3 \%)$ were foreign and 34.7 of guests were Egyptian. This result showed that hotels target international tourism more than internal tourism. According to educational level, $51.2 \%$ of respondents had a university educational degree, and $25.4 \%$ were have a vocational/Secondary School degree, this was followed by guests whose have an institutional qualification with $17.8 \%$. Postgraduate guests were the smallest group and presented by $(5.6 \%)$.

Table 4: Knowledge Awareness of Guests.

\begin{tabular}{|c|c|c|c|c|c|c|}
\hline Attributes & $\overline{\mathbf{x}}$ & SD & C.V & $\mathbf{R}$ & $t$-test & $\begin{array}{c}P- \\
\text { Value }\end{array}$ \\
\hline \multicolumn{7}{|c|}{ Complaints Delivering accessibility } \\
\hline $\begin{array}{l}\text { 1. the hotel distributes guest comment card } \\
\text { on guests during the accomodation }\end{array}$ & 2.81 & .863 & 30.71 & 4 & 7.751 & $.001 \bullet$ \\
\hline $\begin{array}{l}\text { 2. There are instructions inside the hotel } \\
\text { which direct guests to how delivering their } \\
\text { complaints }\end{array}$ & 2.39 & 1.074 & 44.93 & 5 & 9.536 & $.001 \bullet$ \\
\hline $\begin{array}{l}\text { 3. There is a specific department in the } \\
\text { hotel to receive guests' complaints }\end{array}$ & 1.95 & .845 & 43.33 & 6 & 8.159 & $.001 \bullet$ \\
\hline
\end{tabular}




\begin{tabular}{|c|c|c|c|c|c|c|}
\hline Attributes & $\overline{\mathbf{x}}$ & SD & C.V & $\mathbf{R}$ & $t$-test & $\begin{array}{c}P \text { - } \\
\text { Value }\end{array}$ \\
\hline $\begin{array}{l}\text { 4. The hotel interests in guests' review on } \\
\text { hotel evaluating websites such as } \\
\text { Tripadvisor.com }\end{array}$ & 3.19 & .784 & 24.57 & 3 & 9.237 & $.001 \bullet \bullet$ \\
\hline $\begin{array}{l}\text { 5. You were asked about your impression } \\
\text { of the quality of service by the hotel } \\
\text { management }\end{array}$ & 3.94 & .763 & 19.36 & $\mathbf{1}$ & 7.568 & $.001 \bullet \bullet$ \\
\hline $\begin{array}{l}\text { 6. the hotel communicates with guests } \\
\text { after checking out to investigate about } \\
\text { their feedback }\end{array}$ & 3.32 & 1.261 & 37.98 & 2 & 4.204 & $.001 \bullet \bullet$ \\
\hline Average of Responses & 2.93 & 0.931 & 33.48 & $-\cdots$ & $-\cdots$ & $-\cdots$ \\
\hline \multicolumn{7}{|c|}{ Perceived Justice } \\
\hline $\begin{array}{l}\text { 1. The hotel takes care of guest's } \\
\text { complaints }\end{array}$ & 2.27 & .913 & 40.22 & 4 & 7.397 & $.001 \bullet$ \\
\hline $\begin{array}{l}\text { 2. Managers are ready to receive the } \\
\text { complaints }\end{array}$ & 2.94 & .987 & 33.57 & 2 & 2.370 & $.022 \bullet$ \\
\hline $\begin{array}{l}\text { 3. The hotel policy is that the guest is } \\
\text { always right }\end{array}$ & 3.13 & 1.135 & 36.26 & $\mathbf{1}$ & 6.970 & $.001 \bullet \bullet$ \\
\hline $\begin{array}{l}\text { 4. Managers seek to find a solution for } \\
\text { ensuring guests' satisfaction }\end{array}$ & 2.49 & 1.054 & 42.32 & 3 & 4.366 & $.001 \bullet$ \\
\hline $\begin{array}{l}\text { 5. The hotel confesses of his problems and } \\
\text { do not deny it }\end{array}$ & 1.75 & .836 & 47.77 & 5 & 3.017 & $.004 \bullet \bullet$ \\
\hline Average of Responses & 2.52 & 0.985 & 40.01 & ---- & ---- & ---- \\
\hline \multicolumn{7}{|c|}{ Expected Costs and value of Complaining } \\
\hline $\begin{array}{l}\text { 1. Conducting a complaint needs long } \\
\text { procedures and wastes the time }\end{array}$ & 4.16 & .811 & & 2 & -1.503 & .139 \\
\hline 2. Conducting complaints need to follow it & 4.42 & .614 & 13.89 & 1 & -.747 & .459 \\
\hline $\begin{array}{l}\text { 3. Complaining is beneficial to society and } \\
\text { prevents other guests to fall in the same } \\
\text { problem. }\end{array}$ & 3.45 & 1.048 & 30.37 & 3 & 7.348 & $.001 \bullet \bullet$ \\
\hline 4. Complaining requires high fees & 1.78 & .787 & 44.21 & 5 & 4.002 & $.001 \bullet$ \\
\hline $\begin{array}{l}\text { 5. Complaining helps guests to get their } \\
\text { rights back }\end{array}$ & 3.22 & 1.465 & 45.49 & 4 & 4.751 & $.001 \bullet$ \\
\hline Average of Responses & 3.40 & 0.945 & 30.69 & ---- & ---- & ---- \\
\hline
\end{tabular}

The results in Table 4 showed that most of the respondents have not knowledge awareness about complaints delivering accessibility, perceived justice, and expected costs and value of complaining, as the average mean was between 2.52 and 3.40. Also, the results showed that there are significant differences among respondents towards the attributes of the table above which $\mathrm{p}$ value $\leq(.01)$.

Regarding the dimension of complaints delivering accessibility, the respondents showed neutral tendency towards most of the attributes and that means they have not knowledge enough about complaints delivering accessibility. In details, the sample believed that the hotel management interests in investigating guests' impression of the quality of service, as mean $=3.94, \mathrm{CV}=$ 19.36. This belief coincides with the view explained that it is very important for hotels' management to solve problems derived from guest complaints (Kim et al., 2010). However, the respondents have not information enough about that if the hotel communicate with guests after checking out to investigate about their feedback (mean $=3.32, \mathrm{CV}=37.98$ ), also they in doubt 
that the hotel interests in guests' review on hotel evaluating websites (mean=3.19, CV=24.57). this result agreed with Tag-Eldeen (2018) who explained that some people do not complain because they are unfamiliar with the systems or channels for complaints. Moreover, they did not know if the hotel distributes guest comment card on guests or not (mean=2.81, CV=30.71). On other hand, guests disagreed that the hotel have instructions which direct guests to how delivering their complaints as mean $=2.39, \mathrm{CV}=44.93$. Also, they disagreed that there is a specific department in the hotel to receive guests' complaints as mean $=1.95, \mathrm{CV}=43.33$.

According to the dimension of perceived justice, the respondents showed negative tendency towards most of the attributes and that means they did not realize that there is justice in hotels towards complaints handling. In details, the respondents have not information enough about the hotel policy of complaints handling (mean $=3.13, \mathrm{CV}=36.26$ ), also they in doubt that managers are ready to receive the complaints (mean $=2.94, \mathrm{CV}=33.57$ ). On the other hand, guests did not realize that managers seek to find a solution for ensuring guests' satisfaction as mean $=2.49, \mathrm{CV}=$ 42.32. Also, they disagreed that the hotel takes care of guests' complaints as mean=2.27, CV= 40.22. Moreover, they strongly disagreed that the hotel confesses of his problems and do not deny it (mean=1.75, CV= 47.77). in this sense, it should be noticed that the efficacy of complaining and the hotels willingness to solve complaints can be a major factor in guest complaint behavior Vincent and Lam (2003).

Regarding the dimension of expected costs and value of complaining, the respondents showed a positive tendency towards most of the attributes and that means they convinced that however complaining is costed, it also valuable. This result in contrast with Simon et al., (2015) who reported that only 1 out of 20 customers would complain as they do not have the time or the energy to complain. In details, the sample strongly agreed that conducting complaints need to follow it, as mean $=4.42, \mathrm{CV}=13.89$. This belief coincides with the view explained that it is very important for hotels' management to solve problems derived from guest complaints. In the same sense, they believe that conducting a complaint needs long procedures and wastes the time (mean $=4.16, \mathrm{CV}=19.49)$. Also, they agreed that complaining is beneficial to society and prevents other guests to fall in the same problem (mean $=3.45, \mathrm{CV}=30.37)$. Erdogan and Norman (2011) set some of factors that increase the tendency to complain and record that complaining is beneficial to society. However, the respondents in doubt that complaining helps guests to get their rights back (Mean $=3.22, \mathrm{CV}=45.49$ ). On other hand, guests strongly disagreed that complaining requires high fees as Mean $=1.78, \mathrm{CV}=44.21$.

Table 5: Guests Complaining Behavior.

\begin{tabular}{|c|c|c|c|c|c|c|}
\hline Attributes & $\overline{\mathbf{x}}$ & SD & C.V & $\mathbf{R}$ & $t$-test & $\begin{array}{c}P- \\
\text { Value }\end{array}$ \\
\hline $\begin{array}{l}\text { 1. writing a negative review on hotel } \\
\text { evaluation websites/social media }\end{array}$ & 4.29 & .774 & 18.04 & 2 & 11.421 & $.001 \bullet$ \\
\hline $\begin{array}{l}\text { 2. discussing the problem with a manager } \\
\text { or other employee of the hotel. }\end{array}$ & 3.42 & 1.014 & 29.64 & 5 & 8.017 & $.001 \bullet$ \\
\hline $\begin{array}{l}\text { 3. checking out of the hotel and avoided } \\
\text { booking the hotel from then on. }\end{array}$ & 2.87 & 1.106 & 38.53 & 7 & 10.538 & $.001 \bullet$ \\
\hline $\begin{array}{l}\text { 4. speaking to my friends and relatives } \\
\text { about my bad experience. }\end{array}$ & 4.48 & .614 & 13.70 & 1 & 9.007 & $.001 \bullet$ \\
\hline $\begin{array}{l}\text { 5. booking services from another hotel the } \\
\text { next time }\end{array}$ & 3.65 & 1.100 & 30.13 & 4 & 7.441 & $.001 \bullet$ \\
\hline $\begin{array}{l}\text { 5. writing a comment card or completing a } \\
\text { guest survey about the problem(s). }\end{array}$ & 3.84 & .770 & 20.05 & 3 & 6.920 & $.001 \bullet$ \\
\hline
\end{tabular}




\begin{tabular}{|c|c|c|c|c|c|c|}
\hline 7. I took legal action against the hotel. & 3.06 & 1.019 & 33.30 & $\mathbf{6}$ & 9.374 & $.001 \cdot \bullet$ \\
\hline Average of Responses & $\mathbf{3 . 6 5}$ & $\mathbf{0 . 9 1 3}$ & $\mathbf{2 6 . 1 9}$ & ---- & --- & ---- \\
\hline
\end{tabular}

$\mathbf{N}=377 \quad \overline{\mathbf{x}}$ : Mean $\quad$ SD: Standard Deviation $\quad$ R: Rank $\quad$ CV: Coefficient Variance * sig. $\leq(.05) \quad$ *sig. $\leq(01)$

The results in Table 5 showed that most of the respondents will take an action in case service failure, as the Average Mean was 3.65. Also, the results showed that there is significant differences among respondents towards the attributes of the table above which p-value $\leq(.01)$.

Regarding guests complaining behavior, the respondents strongly agreed that they will take a great negative action through speaking to friends and relatives about their bad experience (mean= 4.48, CV = 13.70). This result agrees with $\mathrm{Li}(2010)$ finding that if the guests' responsiveness or hotel-related failure from hotels causes guests dissatisfaction, guests are more likely to tell others about their unhappiness. in addition to writing a negative review on hotel evaluation websites/social media (mean $=4.29, \mathrm{CV}=18.04$ ). Moreover, they behave to write their feedback on a comment card or by completing a guest survey (mean=3.84, CV $=20.05$ ). In addition, some of respondents found booking services from another hotel the next time is a good action (mean= $3.65, \mathrm{CV}=30.13$ ). On the other hand, some of respondents preferred to discuss the problem with a manager or other employee of the hotel (mean $=3.42, \mathrm{CV}=29.64$ ). In other sense, the respondents weren't sure to take a legal action against the hotel (mean $=3.06, \mathrm{CV}=33.30$ ), or checking out of the hotel in case of occurring a problem (mean $=2.87, \mathrm{CV}=38.53)$.

\section{Testing hypotheses}

Table 6: Simple/Multiple Regression.

\begin{tabular}{|c|c|c|c|c|c|c|c|}
\hline $\begin{array}{c}\text { Independent } \\
\text { Variables }\end{array}$ & $*$ Sig & $\mathbf{R}$ & $\mathbf{R}^{2}$ & $\mathbf{F}$ & Tabuled F & T-Test & Tabuled T \\
\hline $\begin{array}{c}\text { knowledge } \\
\text { awareness }\end{array}$ & $* * 0.000$ & 0.884 & 0.728 & 386.945 & 0.600 & -- & -- \\
\hline \multicolumn{7}{|c|}{ Knowledge Awareness Dimensions } \\
\hline $\begin{array}{c}\text { complaints } \\
\text { accessibility }\end{array}$ & $* * 0.000$ & 0.859 & 0.739 & --- & -- & 30.309 & 1.96 \\
\hline perceived justice & $* * 0.000$ & 0.774 & 0.600 & --- & --- & 22.086 & 1.96 \\
\hline $\begin{array}{c}\text { expected costs } \\
\text { and value of } \\
\text { complaining }\end{array}$ & $* * 0.000$ & 0.709 & 0.503 & -- & --- & 18.146 & 1.96 \\
\hline
\end{tabular}

$* *$ sig. $\leq(.01)$

It is noticed from the Table 6; the values of the Parameters of Regression are less than 0.01. It means there is a significant effect of knowledge awareness on guests' intention to complaint at the 0.01 level of significance $(\mathrm{R}=0.884)$. complaints delivering accessibility ranked as the first factor which effect on guests' complaint behavior $(\mathrm{R}=0.859)$. This result means that guests usually did not complain inside the hotel because they do not know to whom they should complain, so they prefer to complain outside. Perceived justice was ranked as the second factor $(\mathrm{R}=0.774)$, the reason of preferring guests to take no action to their realization that the hotel will not take their complaint seriously. Finally, expected costs and value of complaining as last factor which effect on guests' complaint behavior $(\mathrm{R}=0.709)$.

Table 7: T-Test/One-Way ANOVA Test.

\begin{tabular}{|c|c|c|c|c|c|}
\hline Demographic Data & Tabuled F & F & Tabuled T & T-Test & $*$ Sig \\
\hline Gender & --- & --- & 1.96 & 0.398 & 0.691 \\
\hline Educational Level & 2.60 & 3.885 & --- & --- & $* * 0.009$ \\
\hline Nationality & --- & --- & 1.96 & 5.994 & $* * 0.000$ \\
\hline
\end{tabular}

$* *$ sig. $\leq(.01)$ 
Regarding Table 7, the results of T-Test for two independent sample showed that, there is no significant differences among guests in knowledge awareness about complaint back to gender which $\mathrm{t}$-test $=0.398$ and it is less than tabuled- $\mathrm{t}=1.96, \mathrm{P}$-value $=0.691$ (more than 0.5). Meanwhile there is a significant difference among guests in knowledge awareness about complaint back to nationality which $\mathrm{t}$-test $=5.994$ and it is more than tabuled- $\mathrm{t}=1.96$, $\mathrm{P}$-value $=$ **0.000 (less than 0.1). The results of One-Way ANOVA test showed that, there is a significant difference among guests in knowledge awareness about complaint back to educational level which $\mathrm{F}$ value $=3.885$ and it is more than tabuled $-\mathrm{F}=2.60, \mathrm{P}$-value $=* * 0.009$ (more than 0.1$)$. This result in agreement with Salleha et al. (2015) found that people with higher education tend to avoid public complaint behavior.

\section{Conclusion}

This paper has presented an investigation into determining the effect of guests' awareness towards complaints delivering accessibility, perceived justice, and expected costs and efforts of complaining on their complaint's behaviors. It was found out that analyzing the relationship between guests' awareness and their complaints behavior is quite an important way for encouraging guests to leave their complaints inside the hotel instead of taking it outside the hotel, which surely will make a negative effect on the hotel's reputation. Guests haven't knowledge enough about complaints delivering accessibility or the entity they should go when they face a problem or bad service, this may be a main reason for taking negatively action about their experience after checking out. Most guests didn't realize that there is justice in hotels towards complaints handling. This is may back to the lack of information that provided to guests about the hotel's policy in complaint handling. The absence of perceived justice makes the guest loses the trust of the hotel and its efforts in solving his problem. Guests convinced that however complaining is costed, it also valuable, so however they realize complaining process taking from them much time and effort, they tend to complain when they take bad service.

With regard to guests complaining behavior, the respondents usually take a great negative action through speaking to friends and relatives about their bad experience, in addition to writing a negative review on hotel evaluation websites/social media. Moreover, they behave to write their feedback on a comment card or by completing a guest survey. In addition, some of respondents found booking services from another hotel the next time is a good action. On the other hand, some of respondents prefer to discuss the problem with a manager or other employee of the hotel. Finally, there is a significant effect of knowledge awareness dimensions (complaints delivering accessibility, perceived justice, and expected costs and efforts of complaining) on guests' intention to complaint. Therefore, hotels managements should be concern in improving guests' knowledge about their rights and the procedures they can follow to complain. Increasing knowledge awareness for guests make them satisfy and increase their loyalty.

\section{Recommendations Addressed to Hotels Managements}

According to the literature review and the results extracted from the field study, the following recommendations could be suggested:

1. Putting guidelines and instructions in clear places inside the hotel which direct guests to how delivering their complaints.

2. Designing a brochure clarifies the procedures of complaining or giving guests feed-back. This brochure is delivered to guest when his checking in or it could be leave in a clear place in his room (i.e., beside T.V). 
3. Increasing the role of guest relation department in establishment trust links between guests and hotel with taking in consideration the variance between guests in cultures or educational level, that by announcing them that the hotel interests in their complaints and take it seriously.

4. Focusing on giving a feed-back to guests about their complains. This technique make guests feel that their complains are important from hotel perspective.

5. Developing data base about guests complains and its drivers, motives, then links these data with guests' characteristics/demographical background.

\section{References}

Aljasser I. A., and Sasidhar B., (2013). Gender Effect on Customer Satisfaction in Banking Sector: A Study of Banks in Saudi Arabia. Interdisplinary Journal of Research in Business, 3(5), 9-15.

Badghish S., Stanton J., and Hu J., (2015) An Exploratory Study of Customer Complaint Behaviour (CCB) in Saudi Arabia, Asian Journal of Business Research, DOI 10.14707/ajbr.150004

Buttle, F. (2004). Customer Relationship Management: Concepts and Tools. Elsevier, Oxford.

Cambra-Fierro, J., Melero-Polo, I. and Javier S., F. (2015). Can complaint handling efforts promote customer engagement? Service Business, 10, 847-866.

Chan G. S. H., Tang I. L. F., and Sou A. H. K., (2017), An Exploration of Consumer Complaint Behavior towards the Hotel Industry: Case Study in Macao, International Journal of Marketing Studies, 9(5) doi:10.5539/ijms.v9n5p56

Chelminski, P. and, Robin A., C., (2011). An Examination of Consumer Advocacy and Complaining Behavior in the Context of Service Failure, Journal of Services Marketing, 25(5), 361-370.

Dahl, A., and Peltier, J. (2015). A historical review and future research agenda for the field of consumer satisfaction, dissatisfaction, \& complaining behavior. Journal of Consumer Satisfaction, Dissatisfaction and Complaining Behavior, 28, 5-25.

Demirci, B., Bayraktaroğlu, E. and Seçilmiş, C. (2015). Evaluation of Consumer Complaints in Five-Star Hotels: The Case of Eskişehir, Tourism Academic Journal, 2(1), 16-21.

EHA (Egyptian Hotel Association) (2016), The Guide of Hotels in Sharm El-Shiekh City.

Einwiller, S. A. and Steilen, S. (2015). Handling complaints on social network sites-An analysis of complaints and complaint responses on Facebook and Twitter pages of large US companies. Public Relations Review, 41, 195-204.

Emir O. (2011), Customer complaints and complaint behaviors in Turkish hotel restaurants: An application in Lara and Kundu areas of Antalya, African Journal of Business Management, 5(11), 4239-4253

Erdogan H. E., and Norman A., (2011). Comparing Chinese and American attitudes towards complaining, International Journal of Contemporary Hospitality Management, 23(3), 327343

Filip, A. (2013). Complaint Management: A Customer Satisfaction Learning Process. Procedia Social and Behavioral Sciences, 93, 271-275.

Istanbulluoglu D. (2017). Complaint handling on social media: the impact of multiple response times on consumer satisfaction, Computers in Human Behavior, doi: 10.1016/j.chb.2017.04.016 
Kim, M. G., Wang, C. and Mattila, A. S. (2010). The relationship between consumer complaining behavior and service recovery: An integrative review, International Journal of Contemporary Hospitality Management, 22(7), 975-991

Li, M., (2010). Exploration of Chinese consumer complaint behavior in the hospitality industry. Published Thesis, University of Nevada, Las Vegas.

Mousavi M., and Esfidani M. R., (2013). A Comprehensive Model of Customers' Complaint Behavior, International Journal of Academic Research in Business and Social Sciences $3(5), 1-22$

Namkung, Y., Jang, S. and Choi S., K. (2011), Customer complaints in restaurants: Do they differ by service stages and loyalty levels? International Journal of Hospitality Management, 30, 495-502

Nikbin, D., Ismail, I., and Marimutho, M. (2012). The relationship between informational justice, recovery satisfaction, and loyalty: the moderating role of failure attributions, Service Business, 7, 419-435.

Ramphal R. R. (2016). A Complaints Handling System for the Hospitality Industry, African Journal of Hospitality, Tourism and Leisure, 5(2): 1- 15.

Ro, H. and Wong, J. (2012). Customer opportunistic complaints management: A critical incident approach. International Journal of Hospitality Management, 31(2): 419-427.

Salim, A., Setiawan, M., Rofiaty, R., Rohman, F. (2017). "How to Build Satisfaction and Customer Loyalty with a Focus On Complaints Handling" (Review of the Scientific Literature). Journal of Finance and Banking Review, 2(2), 28-33.

Salim A., Setiawan M., Rofiaty R., and Rohman F. (2018), "Focusing on Complaints Handling for Customer Satisfaction and Loyalty: The Case of Indonesian Public Banking", European Research Studies Journal, 3, 404-416.

Salleha M.Z., Saidb M. A., Abu Bakara E., Alia A. M., and Zakariaa I., (2015) "Gender Differences among Hotel Guest towards Dissatisfaction with Hotel Services in Kuala Lumpur", Procedia Economics and Finance, 37 (1), 27 - 32

Simon, A., Kafel, P., Nowicki, P. \& Casadesus, M. (2015). The development of complaints handling standards in SPA companies: A case study analyses in Spain. International Journal for Quality Research, 9(4), 675-688.

Sparks, B. A. and McColl-Kennedy, J. R. (2001). Justice strategy options for increased customer satisfaction in a services recovery setting. Journal of Business Research, 54(3), 209-218.

Tag-Eldeen, A. (2018) "Assessing the Impact of Complaints Management System in Hospitality Organizations in Egypt: A Customer-organization Perspective", Journal of Tourism \& Management Research, 3 (2): 306-317

Thompson, S. K., (2012) "Sampling”, Third Edition, John Wiley \& Sons, Inc, U.S, 59-60.

Verhagen, T., Nauta, A., and Feldberg, F. (2013). Negative online word-of-mouth: Behavioral indicator or emotional release? Computers in Human Behavior, 29, 1430 - 1440.

Vincent C.S. and Lam H. T., (2003),"Customer complaint behavior towards hotel restaurant services", International Journal of Contemporary Hospitality Management, 15(5), 283 289

Zheng T., Youn H. and Kincaid C. S. (2009) An Analysis of Customers' E-Complaints for Luxury Resort Properties, Journal of Hospitality Marketing \& Management, 18(7), 718729. 